\title{
CHOICE OF FOREIGN MARKET ENTRY MODE: IMPACT OF OWNERSHIP, LOCATION AND INTERNALIZATION FACTORS
}

\author{
Sanjeev Agarwal* and Sridhar N. Ramaswami** \\ Iowa State University
}

\begin{abstract}
Firms interested in servicing foreign markets face a difficult decision with regards to the choice of an entry mode. The options available to a firm include exporting, licensing, joint venture and sole venture. Several factors that determine the choice of a specific foreign market entry mode have been identified in previous literature. These factors can be classified into three categories: ownership advantages of a firm, location advantages of a market, and internalization advantages of integrating transactions. This study examines the independent and joint influences of these factors on the choice of an entry mode. Multinomial logistic regression model is employed to test the hypothesized effects.
\end{abstract}

\section{INTRODUCTION}

A firm seeking to enter a foreign market must make an important strategic decision on which entry mode to use for that market. The four most common modes of foreign market entry are exporting, ${ }^{1}$ licensing, joint venture, and sole venture. Because all of these modes involve resource commitments (albeit at varying levels), firms' initial choices of a particular mode are

\footnotetext{
*Sanjeev Agarwal (Ph.D., The Ohio State University) is Assistant Professor in the Department of Marketing at Iowa State University. His research interests include multinational marketing strategies, salesforce management, and environmentalism. He has previously published in Advances in International Marketing and International Trade Journal and contributed to national and international conference proceedings.

${ }^{* *}$ Sridhar N. Ramaswami (Ph.D., The University of Texas at Austin) is Assistant Professor in the Department of Marketing at Iowa State University. His research interests include multinational marketing strategies, organizational adaptation and effectiveness, inter-organizational relations, and self-management behavior of marketing employees. He has previously published in International Journal of Research in Marketing and Technology Forecasting and Social Change, and contributed to national and international conference proceedings.
}

The authors would like to thank Jean J. Boddewyn, Farok J. Contractor, Hubert A. Gatignon, V. Kumar, Sameer Sikri, Rajendra K. Srivastava, and three anonymous reviewers for their comments on earlier versions. The authors contributed equally to this manuscript and are solely responsible for any content and remaining errors.

Received: July 1990; Revised: November 1990, February \& May 1991; Accepted: June 1991. 
difficult to change without considerable loss of time and money [Root 1987]. Entry mode selection is therefore, a very important, if not a critical, strategic decision.

Previous studies in the areas of international trade, industrial organization, and market imperfections have identified a number of factors that influence the choice of an entry mode for a selected target market. Integrating perspectives from these areas, Dunning [1977, 1980, 1988] proposed a comprehensive framework, which stipulated that the choice of an entry mode for a target market is influenced by three types of determinant factors: ownership advantages of a firm, location advantages of a market, and internalization advantages of integrating transactions within the firm. Several empirical studies have attempted to directly or indirectly use the Dunning framework in explaining choice between joint venture and sole venture [Kogut and Singh 1988], licensing and sole venture [Caves 1982; Davidson and McFetridge 1985], extent of foreign direct investment [Cho 1985; Dunning 1980; Kimura 1989; Sabi 1988; Terpstra and Yu 1988; Yu and Ito 1988], and ratio of acquisition to total subsidiaries [Wilson 1980].

While these studies have made substantial contributions to our understanding of the entry mode behavior of firms, an important gap in the empirical literature is the issue of how the inter-relationships among the determinant factors influence firms' entry choices. ${ }^{2}$ The importance of examining the effects of inter-relationships derives from the fact that they may explain firm behaviors that cannot be captured by the independent effects of the factors. For example, firms that have lower levels of ownership advantages are expected to either not enter foreign markets or use a low-risk entry mode such as exporting. However, many such firms have been observed to enter foreign countries, especially those that have high market potential, using joint ventures and licensing arrangements [Talaga, Chandran \& Phatak 1985]. This type of firm behavior can be better explained if the joint effect of ownership advantages of the firm and location advantages of the market is examined. A critical theme that this study pursues is the examination of a number of such firm behaviors by evaluating the joint impact of a set of determinants.

A methodological feature of this study is the use of the survey technique to obtain information on the determinant factors. An important advantage of this technique is that it provides direct measures (as compared to proxy variables used by most researchers) of both location and internalization factors. The direct measures are obtained by evaluating managerial perceptions about market potential and investment risks (location advantages), and costs of writing and enforcing contracts, risk of deterioration in the quality of services, and risk of dissipation of knowledge (internalization advantages) in a given host country. Perceptual measures are particularly useful in the measurement of internalization advantages since past experience has shown that it is a difficult construct to quantify. Unlike location advantages, 
indicators of internalization advantages have not been appropriately identified in the entry mode literature to date. ${ }^{3}$

Managerial perceptions are also relevant for the assessment of the location advantages of a specific country. While previous research has assumed that the location advantages are exogenous ${ }^{4}$ and hence constant across firms for a given host country, our study allows us to measure these variables as a function of the perceptions of managers. It should be noted that these perceptions may be different due to variations in managers' past experiences in that country (and other countries), level of knowledge about that country, individual biases, etc. There is wide support from the organizational behavior literature for the importance of managerial perceptions in decisionmaking [Cyert and March 1963].

The remainder of the paper is organized into three parts. The first part reviews the relevant literature to develop the hypotheses. The second part details the research setting, the operational measures, data collection, and research method. The last section provides the results and discusses important managerial, theoretical, and public policy implications.

\section{LITERATURE REVIEW AND HYPOTHESES}

Normative decision theory suggests that the choice of a foreign market entry mode should be based on trade-offs between risks and returns. A firm is expected to choose the entry mode that offers the highest risk-adjusted return on investment. However, behavioral evidence indicates that a firm's choices may also be determined by resource availability and need for control [Cespedes 1988; Stopford and Wells 1972]. Resource availability refers to the financial and managerial capacity of a firm for serving a particular foreign market. Control refers to a firm's need to influence systems, methods, and decisions in that foreign market [Anderson and Gatignon 1986]. Control is desirable to improve a firm's competitive position and maximize the returns on its assets and skills. Higher operational control results from having a greater ownership in the foreign venture. However, risks are also likely to be higher due to the assumption of responsibility for decisionmaking and higher commitment of resources.

Entry mode choices are often a compromise among these four attributes. The exporting mode is a low resource (investment) and consequently low risk/return alternative. This mode, while providing a firm with operational control, lacks in providing marketing control that may be essential for market seeking firms. The sole venture mode, on the other hand, is a high investment and consequently high risk/return alternative that also provides a high degree of control to the investing firm. The joint venture mode involves relatively lower investment and hence provides risk, return, and control commensurate to the extent of equity participation of the investing firm. Finally, the licensing mode is a low investment, low risk/return alternative which provides least control to the licensing firm. 
By including firm-specific and market-specific factors that influence these criteria (control, return, risk, and resources), Dunning [1977, 1980, 1988] developed a framework for explaining choice among exporting, licensing, joint venture, and sole venture modes (see Figure 1). A brief description of the main effects of these factors is presented below and is mainly used for validating the results of this study. The main thrust of this research is on examining the effects of interrelationships among these independent factors. A detailed discussion of these effects is presented in the next section.

\section{Ownership Advantages}

To compete with host country firms in their own markets, firms must possess superior assets and skills that can earn economic rents that are high enough to counter the higher cost of servicing these markets. A firm's asset power is reflected by its size and multinational experience, and skills by its ability to develop differentiated products.

When a firm possesses the ability to develop differentiated products, it may run the risk of loss of long-term revenues if it shares this knowledge with host country firms. This is because the latter may acquire this knowledge and decide to operate as a separate entity at a future date. This risk is especially relevant for international transactions because interorganizational infrastructures are often poorly developed, likely to change frequently, and particularly weak across national boundaries [Van de Ven and Poole 1989]. Therefore, when the firm possesses these skills, higher control modes may be more efficient. There is substantial empirical support for the use of higher control modes with higher levels of product differentiation [Anderson and Coughlan 1987; Caves 1982; Coughlan 1985; Coughlan and Flaherty 1983; Davidson 1982; Stopford and Wells 1972].

Firms need asset power to engage in international expansion and to successfully compete with host country firms. Resources are needed for absorbing the high costs of marketing, for enforcing patents and contracts, and for achieving economies of scale [Hood and Young 1979]. The size of the firm reflects its capability for absorption of these costs [Buckley and Casson 1976; Kumar 1984]. Empirical evidence indicates that the impact of firm size on foreign direct investment is positive [Buckley and Casson 1976; Cho 1985; Caves and Mehra 1986; Yu and Ito 1988; Terpstra and Yu 1988; Kimura 1989]. In other words, the size of the firm is expected to be positively correlated with its propensity to enter foreign markets in general, and to choose sole and joint venture modes in particular. While the preference for sole ventures is not surprising, the choice of joint ventures may be explained by the fact that a larger organization may be less concerned than a smaller organization with the potential possibility of exploitation by the host country partner [Doz 1988].

Another form of asset power, a firm's level of multinational experience, has also been shown to influence entry choices. Firms without foreign market 
FIGURE 1

\section{A Schematic Representation of Entry Choice Factors}

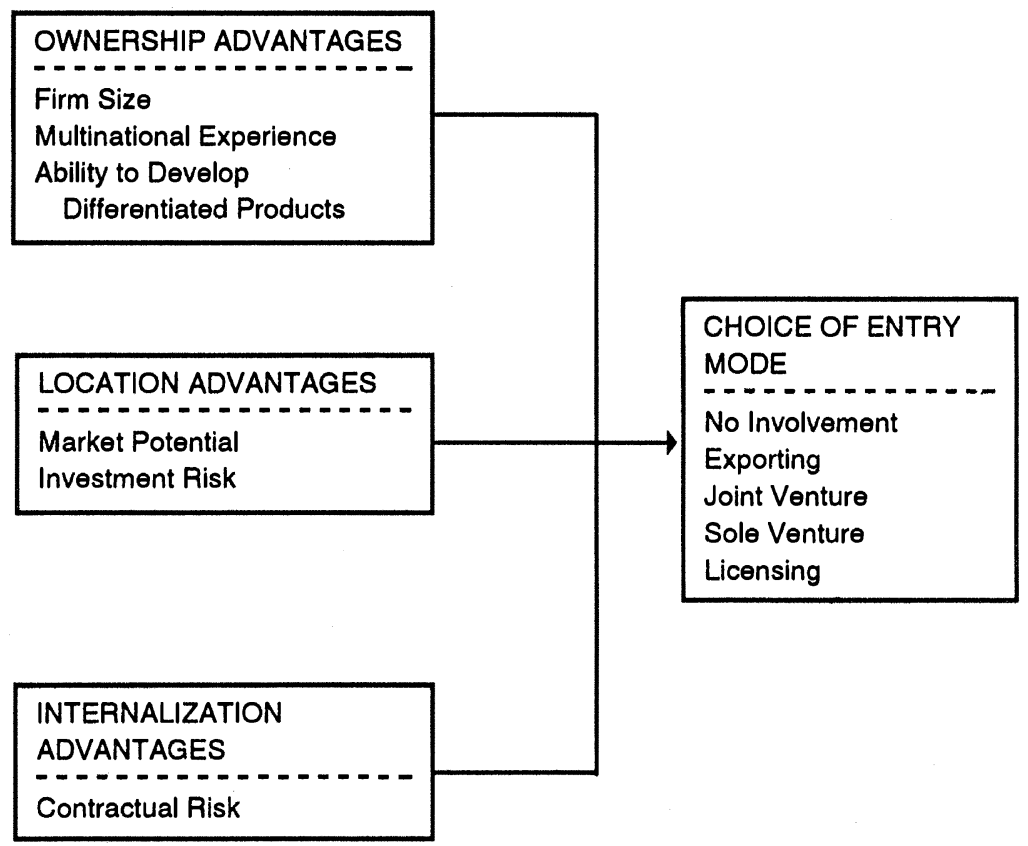

experience are likely to have greater problems in managing foreign operations. They have been observed to overstate the potential risks, while understating the potential returns of operating in a foreign market. This makes choice of non-investment modes more probable for these firms [Caves and Mehra 1986; Gatignon and Anderson 1988; Terpstra and Yu 1988]. Conversely, firms with higher multinational experience may be expected to prefer investment modes of entry.

\section{Location Advantages}

Firms interested in servicing foreign markets are expected to use a selective strategy and favor entry into more attractive markets. This is because their chances of obtaining higher returns are better in such markets. The attractiveness of a market has been characterized in terms of its market potential and investment risk. $^{5}$

Market potential (size and growth) has been found to be an important determinant of overseas investment [Forsyth 1972; Weinstein 1977; Khoury 1979; Choi, Tschoegl and Yu 1986; Terpstra and Yu 1988]. In high market potential countries, investment modes are expected to provide greater longterm profitability to a firm, compared to non-investment modes, through the opportunity to achieve economies of scale and consequently lower marginal 
cost of production [Sabi 1988]. Even if scale economies are not significant, a firm may still choose investment modes since they provide the firm with the opportunity to establish long-term market presence.

The investment risk in a host country reflects the uncertainty over the continuation of present economic and political conditions and government policies which are critical to the survival and profitability of a firm's operations in that country. Changes in government policies may cause problems related to repatriation of earnings, and in extreme cases, expropriation of assets [Root 1987]. Researchers have suggested that the restrictive policies of a host country's government are likely to impede inward foreign investments [Rugman' 1979; Stopford and Wells 1972]. In these countries, a firm would be better off not entering; but if it does, it may favor use of non-investment options.

\section{Internalization Advantage (Contractual Risk)}

Low control modes are considered superior for many transactions since they allow a firm to benefit from the scale economies of the marketplace, while not encountering the bureaucratic disadvantages that accompany integration [Williamson 1985]. However, low control modes will have a higher cost compared to integrating the assets and skills within the firm if managers are unable to predict future contingencies (problem of bounded rationality/external uncertainty) and if the market is unable to provide competing alternatives (problem of small numbers/opportunism). High external uncertainty, given bounded rationality, makes the writing and enforcement of contracts that specify every eventuality and consequent response more expensive [Anderson and Weitz 1986]. Similarly, the small numbers problem makes the enforcement of contracts meaningless and possibly inefficient since the firm may not find other partners. Under these conditions, exporting and sole venture modes provide better control due to retaining of the assets and skills within the firm.

\section{EFFECTS OF INTERRELATIONSHIP AMONG DETERMINANT FACTORS}

\section{Size/Multinational Experience and Market Potential}

The above discussion of the main effects suggests that investment modes would be preferred (a) by firms that are larger and that have more multinational experience, and (b) in countries that are perceived to have high market potential. Therefore, we can expect their combined impact to result in a preference for investment modes when both factors are high, and a preference for no involvement when both factors are low. This expectation is trivial as it does not add any new information about firms' behavior except maybe strengthening the direct effects of each factor. A more interesting question is how larger and more multinational firms respond in countries that have relatively lower market potential, and vice versa. A cursory review of actual 
firm choices shows that investment modes may be chosen by larger multinational firms even in low potential countries, and by smaller and less multinational firms in high potential countries.

Countries that have relatively lower market potential can be expected to have a lower likelihood of attracting foreign firms. However, firms that are larger and that have a regional or worldwide presence may be interested in entering these markets for achieving their growth and profit objectives. Note, for example, that developing countries such as Brazil and India, even though not as attractive as the developed countries, may still have sufficient potential and strategic importance to warrant consideration. An additional benefit offered by these target markets is the opportunity for higher returns (in excess of the risks taken) due to the presence of greater market imperfections. Ecological models predict that only larger organizations have the resources required to bear the risks associated with entering low potential markets [Lambkin 1988].

If these firms do decide to enter relatively lower potential markets, they may have a higher propensity to choose a sole venture mode to satisfy their strategic need to coordinate activities on a global basis [Bartlett 1986; Bartlett and Ghoshal 1986; Doz, Prahalad and Hamel 1988]. Research on global strategy has suggested that such firms will or should be more concerned with global strategic position than with the transaction costs associated with a given market [Porter and Fuller 1986]. Though exporting and joint venture arrangements may be more appropriate for low potential markets from a risk reduction perspective, they may not allow the strategic control, change, and flexibility that are needed to secure long-term global competitiveness. The presence of joint venture partners, in particular, can create an impediment to strategic coordination. Their motivations are often incongruent with that of the investing firm, which can lead to significant difficulties [Prahalad and Doz 1987]. On the other hand, firms can gain competitive advantage by exploitation of the strategic options provided by integrated operations [Kogut 1989]. They can spot opportunities and threats that may be beyond the horizon of individual operations; they can bring the full weight of their resources to bear on selected competitors or markets; they can shift resources across national boundaries very easily; and they can use the experience gained in one country in another where it may be relevant.

In addition to the above strategic advantages, globally integrated firms prefer complete control of their foreign operations because overall profit maximization requires that their foreign ventures be tightly subordinated to the parents. Thus:

H1: Firms that are larger and that have higher multinational experience, are more likely to choose a sole venture for entry in relatively lower market potential countries.

Firms that are smaller and have lower multinational experience are not expected to have sufficient resources or skills to enter a large number of 
foreign markets. They therefore can be expected to use a selective strategy and concentrate their efforts in the more potential foreign markets. This is because their chances of obtaining higher returns are better in such markets. In addition, resource limitations (including size) make them prone to utilize proportionately more joint ventures than do industry leaders [Contractor and Lorange 1988; Fayerweather 1982; Stopford and Wells 1972]. Joint venture arrangements allow them to share costs and risks, as well as complementary assets and skills with host country partner firms [Harrigan 1985]. By doing so, a firm is able to reduce the long-term uncertainty at a lower cost than through pure hierarchical or market approaches [Beamish and Banks 1987].

$\mathrm{H} 2$ : Firms that are smaller and that have lower multinational experience are more likely to choose a joint venture mode in countries that have a higher perceived market potential.

\section{Ownership Advantages and Investment Risk}

In environments characterized by high investment risks, the main effect suggested that firms are better off not entering, and exporting rather than investing if they do choose to enter. However, firms vary in their capacity to deal with investment risks depending upon their ownership advantages. Specifically, firms with valuable assets and skills (that are needed in these markets) may be able to bargain with host governments for concessions that provide them immunity against investment risks [Leontiades 1985]. If these concessions are not granted, they may be unwilling to enter such markets.

Empirical evidence shows that firms that possess a proprietary product or technology have been able to increase their bargaining position over the host government [Lecraw 1984; Vernon 1983]. On the other hand, firm size and multinationality do not necessarily provide this bargaining advantage [Fagre and Wells 1982]. The primary explanation for this difference is that while a host government may be able to find alternative sources of capital, it may not easily find alternative sources of technology. This implies that desirable technology can command an unusually high degree of leverage and bargaining position even in countries that are characterized by higher investment risks [Ting 1988].

In addition, risk-reducing considerations may push firms that have proprietary products or technology to choose higher control modes. Such modes allow firms to modify their investments in such a way that the assets they place in the foreign country are less profitable to the host government in case they are expropriated [Eaton and Gersovitz 1983]. Without this control, these firms face an omnipresent threat that host governments will change their policies at a future date in favor of local firms. Thus:

H3: Firms that have higher ability to develop differentiated products are more likely to choose a sole venture mode in markets that have high investment risk; on the other hand, firms that are 
larger and have higher multinational experience may have a lower probability of choosing a sole venture mode in such countries.

\section{Ownership Advantages and Contractual Risk}

The main effect of internalization advantage suggested that firms will refrain from entering a country if the perceived risk of dissipation of knowledge, risk of deterioration of quality of services, and costs of writing and enforcing contracts are high. This is particularly critical for firms that have specialized knowledge, protection of which must be an important priority [Hill, Hwang and Kim 1990]. However, these firms are also interested in maximizing the economic rents on their knowledge (as suggested by the main effect of this factor). This creates a decision scenario in which the need for protection will be traded against return potential. Lack of protection would make sharing of specialized knowledge risky in the long run particularly since it would limit the flexibility a firm has in adapting to future contingencies. Since a flexible arrangement is difficult to achieve in a contractual setting, a firm that has specialized knowledge will be expected to opt for an internal organization. On the other hand, when the contractual risks are low, a firm may be more willing to share its specialized knowledge. This is because as the risk of dissipation falls, the opportunity for mutually beneficial contractual arrangements increases at the expense of an internal market [Rugman 1981]. This opportunity also will be higher in countries where the cost of writing and enforcing contracts is low. For those firms that do not possess any specialized knowledge, the presence of contractual risks may not be a critical issue. These firms may be willing to opt for contractual arrangements even when the contractual risks are high [Rugman 1982]. Thus:

H4: Firms that have higher ability to develop differentiated products are likely to choose a sole venture mode in countries characterized by high contractual risks; on the other hand, firms that do not have this ability may choose a contractual mode even when the risks are high.

The contractual risks also do not pose a threat to firms that have ownership advantages arising from size and multinationality as much as they do to ownership advantages arising from its knowledge base and hence are not considered here.

\section{Market Potential and Investment Risk}

The direct effect of high market potential indicates a choice of investment modes, while low market potential indicates a choice of no entry. On the other hand, the direct effect of high investment risk indicates a choice of no entry while low investment risk indicates a choice of investment modes. The combined effect of market potential and investment risk, therefore, for high/low combination should be an investment mode and for low/high combination 
should be no entry. However, it is not clear what modes are likely to be chosen in countries that have high market potential and at the same time are characterized by high investment risks. While this interaction effect is intuitively interesting, a review of the literature did not provide any theoretical rationale or empirical evidence that could help us develop a specific hypothesis. We speculate, however, that the need to establish market presence in high potential countries may be traded against the need to minimize investment risks. Firms may therefore choose to export or create joint ventures because these modes not only insulate them somewhat from investment risks, but also provide access to markets. In the case of exporting, the investment to exploit the foreign market is made in the home country and hence provides immunity from investment risks in the host countries. In the case of joint ventures, a part of the risk is shifted to a partner in the host country who can also help in negotiations with the host government and thus help reduce the investment risk for the firm.

H5: In countries characterized by high market potential and high investment risk, firms may show a higher preference for exporting and joint venture modes.

\section{METHOD}

\section{Research Setting}

In order to test the above hypotheses, the U.S. equipment leasing industry (a service industry) has been chosen for this study. Although the FDI theory was originally developed to explain foreign production, its application to service industries is considered equally appropriate [Boddewyn, Halbrich, and Perry 1986]. The model has been applied in the past to explain the internationalization of the hotel industry [Dunning and McQueen 1981], the banking industry [Cho 1985; Gray and Gray 1981; Sabi 1988; Yannopoulos 1983], and the advertising industry [Terpstra and $Y u$ 1988].

Leasing is a generic term used for all types of secured equipment financing. Any type of equipment can be financed through leasing; some of the typical products that are leased include aircrafts, agricultural equipment, automobiles, computers, containers, health care equipment, and ships. While leasing has been traditionally popular in the U.S., U.K., Germany, and Japan, recent years have seen leasing take on much more importance in countries such as Brazil, Venezuela, South Korea, Hong Kong, and the Philippines. The penetration of leasing (in capital formation) in North America increased from an estimated $14.7 \%$ in 1978 to $25.5 \%$ in 1982 ; the overall penetration worldwide during the same period rose from an estimated $9.2 \%$ to $15.0 \%$ demonstrating the increasing use of leasing in the capital formation of countries worldwide [Clark 1985].

The international leasing business can be divided into two basic categories: (a) cross-border (or export) leasing, and (b) overseas leasing (through foreign 
affiliates/subsidiaries). Cross-border leasing, which is similar to exporting, involves leasing of equipment owned by a firm in one country to a firm in another country. It usually provides for the purchase of the equipment by the lessee at the end of the lease contract period. In most countries, such cross-border leases obtain government financing and guarantees similar to those given to direct exports of equipment [Meidan 1984].

Overseas leasing involves setting up affiliates or subsidiaries through contracts and investments, respectively. These affiliates/subsidiaries draw upon the experience and knowledge of the parent firm for servicing the market in the host country. For example, United States Leasing International, Inc., has contractual arrangements in Australia, Brazil, Colombia, Ecuador, Jordan, Malaysia, Mexico, the Philippines, and Sweden; a sole venture in the United Kingdom; and a joint venture in Japan. In a contractual arrangement, the technical and management know-how possessed by a firm is licensed to a foreign firm. In a joint or sole venture arrangement, a firm attempts to develop a foreign market by directly investing in that market. Leasing firms invest for acquisition of equipment that can be leased in the host country. They can operate alone or in partnership with a local firm. While manufacturing is not carried out by leasing firms, the organizational structures employed by them are no different from those employed by manufacturing firms.

\section{Operational Measures}

Pre-study interviews with fourteen leasing firms were instrumental in devising the operational measures for this study. They were especially important in adapting the measures used in previous literature to the international leasing context.

\section{Ownership Advantages}

Ability to Develop Differentiated Products. Ability to develop differentiated products is measured by the perceived ability of the firm to create new and creatively structured leasing transactions, and the perceived quality of the firm's training program in preparing employees to conduct leasing transactions. The knowledge and skill developed through training has been considered to be important for creating differentiated products [Hood and Young 1979]. The reliability coefficient for this measure was found to be 0.51 .

Firm Size. Firm size is measured by its sales volume. A number of other measures have been used by researchers such as total assets [Dubin 1975; Kogut and Singh 1988; Yu and Ito 1988], equity and deposits [Cho 1985], employee size [Norburn and Birley 1986], and domestic market sales [Kimura 1989]. Since we can expect a high degree of correlation among these variables, we chose the total sales volume of the firm as an indicator of firm size.

Firm's Multinational Experience. A firm's multinational experience is measured in this study using three items: percent of total earnings attributed 
to foreign operations, perceived degree of multinationality, and perceived readiness to handle international business. The reliability coefficient for this measure was found to be 0.81 .

\section{Location Advantages}

Market Potential. The indicators of this measure include perceived managerial assessment of market size, growth potential, acceptability of leasing as a financial tool in the host country, host government's attitudes toward foreign firms in general and the leasing industry in particular. The last two items are important because the leasing industry's potential is critically dependent on the host government's laws (accounting procedures and tax laws) that make leasing attractive as a financing tool. Inter-item correlations indicated good correlation among the five items. The reliability coefficient for this measure was found to be 0.81 .

Investment Risk. Investment risk includes the risk that a host government will interfere with the repatriation of profits and the control of foreign assets, and the risk of a breakdown in the international trade and investment policies of the government [Herring 1983]. These are measured by managerial perceptions of the host government's policies toward conversion and repatriation of profits, expropriation of assets, and the stability of the political, social and economic conditions in the host country. The reliability coefficient for this measure was found to be 0.90 .

\section{Internalization Advantages}

Contractual Risk. The assessment of internalization advantage is based on the relative costs (or risks) of sharing the assets and skills with a host country firm versus integrating them within the firm. Because such costs are difficult to estimate [Buckley 1988], researchers have recommended the measurement of contractual risks associated with sharing the firm's assets and skills [Dunning 1980]. The risks involved in using contracts include costs of making and enforcing contracts in a foreign country relative to the United States, risk of dissipation of proprietary knowledge, and risk of deterioration in the quality of services if operated jointly with a host country partner or licensee. The reliability coefficient for this measure was found to be 0.58 .

All of the above items, except sales and foreign earnings of the firm, were measured on appropriate 7-point bipolar scales. A list of these items is given in the Appendix. Independent assessments of these items were obtained from each firm for three different countries, namely, the United Kingdom, Japan and Brazil. These countries were chosen to reflect different political and economic systems.

\section{Entry Choice}

The dependent variable is the choice of entry mode for a particular country. Respondents indicated their choice preference among five alternatives including 
no involvement, exporting, licensing, joint venture, and sole venture for each of three countries (U.K., Japan, and Brazil) included in this study. ${ }^{6}$

\section{Data Collection}

The preliminary questionnaire instrument comprising the above scales was discussed with the presidents of four leasing companies as well as with three academicians. Based on their comments, some of the questionnaire items were modified. The revised questionnaire was then pre-tested with ten randomly selected firms. The objective of this test was to confirm that the items were understandable and unambiguous. The questionnaire was modified on the basis of comments received during the pre-test.

The population of leasing firms in the U.S. comprised 1196 firms in the year 1986. After excluding firms that were owned by foreign firms, firms whose business was confined to a city or town and that was not even regional or national, and firms which used leasing to support their other primary businesses (e.g. investment bankers), the population was reduced to $\mathbf{5 5 0}$ firms. This was further reduced to $\mathbf{5 3 6}$ firms after excluding firms that were used in preliminary tests. Key informants for the information needed for this study were designated to be either the President or CEO of the firm.

Discussions with executives during the pre-test phase of the study led to the conclusion that only the $\mathrm{CEO} /$ President had complete knowledge required for this study. Efforts were therefore made to make the responses of these key informants as representative of the true situation as possible. The guidelines provided by Huber and Power [1985] for using a single informant in terms of motivation of informants to cooperate with the study seriously, assessment of alternate framing of questions, and use of structured questions were strictly followed in this study. The final questionnaire was mailed to the Presidents or the CEOs of the study sample. The first wave of mailing to 536 firms, followed by a second wave of mailing to 250 firms, yielded responses from 119 firms, resulting in a response rate of $22.8 \%$. Out of the 119 firms, 22 were excluded since they contained large numbers of missing values, resulting in a final sample of 97 firms. Since each firm provided its choices and evaluations for three countries, the total number of observations available for statistical analysis was 285 (six choices had to be omitted due to missing values).

\section{Research Method}

Factor analysis was used to assess the psychometric properties of the study constructs. Since size and multinational experience indicators were highly correlated (and the hypothesized relationships were parallel), these were combined to form a single factor. After confirming the unidimensional nature of the constructs, internal consistency among the items was further 
TABLE 1

Psychometric Properties of Measures

\begin{tabular}{|c|c|c|c|c|c|}
\hline & $\begin{array}{c}\text { Factor } \\
1\end{array}$ & $\begin{array}{c}\text { Factor } \\
2\end{array}$ & $\begin{array}{c}\text { Factor } \\
3\end{array}$ & $\begin{array}{c}\text { Factor } \\
4\end{array}$ & $\begin{array}{c}\text { Factor } \\
5\end{array}$ \\
\hline \multicolumn{6}{|l|}{ A. Product Differentiation } \\
\hline 1. Quality of training program & -.14 & .03 &. .04 & .01 & 80 \\
\hline 2. Innovation potential & .12 & -.06 & .18 & -.01 & .78 \\
\hline \multicolumn{6}{|l|}{ B. Size and Multinational Experience } \\
\hline 1. Firm size & -.05 & .06 & .68 & .06 & .20 \\
\hline 2. Foreign earnings/total earnings & -.07 & .08 & 81 & -.07 & -.09 \\
\hline 3. Perceived multinationality & -.07 & .12 & 88 & -.09 & .09 \\
\hline $\begin{array}{l}\text { 4. Perceived ability to handle } \\
\text { international expansion }\end{array}$ & .06 & .10 & 81 & -.16 & .23 \\
\hline \multicolumn{6}{|l|}{ C. Market Potential } \\
\hline $\begin{array}{l}\text { 1. Acceptability of leasing as a } \\
\text { financial tool }\end{array}$ & 76 & .43 & .05 & -.14 & .05 \\
\hline 2. Market potential & 84 & .36 & -.14 & -.05 & -.02 \\
\hline 3. Growth potential & 74 & .28 & .10 & .04 & .01 \\
\hline \multicolumn{6}{|l|}{ 4. Attitude of government toward } \\
\hline -leasing industry & 80 & .24 & .00 & -.13 & .00 \\
\hline -foreign firms & $\underline{58}$ & .13 & .01 & -.22 & -.04 \\
\hline \multicolumn{6}{|l|}{ D. Investment Risk } \\
\hline 1. Volatility & .33 & .87 & .16 & -.24 & .03 \\
\hline $\begin{array}{l}\text { 2. Risk of converting/repatriating } \\
\text { income }\end{array}$ & .36 & 90 & .07 & -.20 & -.04 \\
\hline 3. Risk of asset expropriation & .40 & .91 & .10 & -.33 & .01 \\
\hline \multicolumn{6}{|l|}{ E. Contractual Risk } \\
\hline $\begin{array}{l}\text { 1. Cost of making and enforcing } \\
\text { contracts }\end{array}$ & -.06 &. .41 & -.14 & $\underline{56}$ & .07 \\
\hline 2. Maintenance of quality standards & -.09 & -.31 & -.08 & .81 & -.17 \\
\hline 3. Risk of dissipation of knowledge & -.18 &. .09 & .00 & .77 & .09 \\
\hline Eigenvalue & 3.30 & 3.17 & 2.68 & 1.90 & 1.45 \\
\hline$\%$ variance explained & 19.4 & 18.7 & 15.8 & 11.2 & 8.6 \\
\hline
\end{tabular}

assessed by estimating coefficient alpha and dropping items with low itemto-total correlations. Finally, the reduced set of items was rechecked for internal consistency via factor analysis, confirming the original unidimensional nature of the constructs obtained [Nunnally 1978]. The factor loadings structure was employed to determine the factor scores of each firm on the five constructs. All the scale items loaded highly on factors (constructs) they represented, and weakly on other factors. The five factors accounted for $73.3 \%$ of the total variation in the sample (see Table 1).

Since the factor scores are expressed as standardized scores, they create a problem when interactions are expressed as products. For example, a low/low combination would yield a large positive term, making low/low and high/high combinations indistinguishable. An interaction is interpretable only if the low/low combination is represented by a smaller number relative to the high/high combination. We have used a transformation suggested by 
Cooper and Nakanishi [1983] of the original factor scores to calculate the interaction term in order to resolve this problem. It involves determining a zeta squared value that is given by the following equation:

$$
\begin{aligned}
\xi_{i j}^{2} & =1+Z_{i j}^{2} & & \text { if } Z_{i j}>0, \\
& =1 /\left(1+Z_{i j}^{2}\right) & & \text { if } Z_{i j}<0,
\end{aligned}
$$

where $Z_{i j}$ is the standardized factor score of firm $i$ on variable $j$. This transformation provides interaction terms that have a lower bound of zero and an upper bound of infinity.

Multinomial logistic regression was then used to obtain the maximum likelihood estimates of the main effect and interaction parameters. Three separate models were evaluated : (1) using "no involvement" as the base case from which deviations are interpreted (Model I), (2) excluding the "no involvement" option and using "exporting" as the base case (Model II), and (3) excluding "no involvement" and "exporting" options and using joint venture as the base case (Model III). All three of these models fit the data very well. A total of $62.5 \%, 68.0 \%$ and $70.3 \%$ of the observations are classified correctly in the three models respectively, compared to $34.0 \%, 48.0 \%$ and $56.6 \%$ that would have been expected due to chance. In addition, two logit models, one including interaction terms and the other excluding these terms, were estimated to determine the overall relevance of the interaction terms. Inclusion of the six interaction terms helped the log likelihood ratio to decrease by $51.81,44.28$, and 5.31, respectively for Models I, II, and III. In addition, the inclusion of the interaction terms resulted in a change in chi-square values by $103.62,88.56$, and 10.64 , respectively for Models I, II, and III, with a corresponding change of 18,12 , and 6 degrees of freedom (also see Table 2). The changes in chi-square values are significant at the .001 level for Models I and II suggesting strong evidence for including the interaction terms in the choice model, and at the .101 level for Model III, suggesting moderate evidence for including the interaction terms in the choice model. The results of the multinomial logistic regression analysis are presented in Table 2. The logistic regression results evaluate the effects of the interacting variables when both are high or low. However, they cannot distinguish the effects of the interacting variables when one of the variables has a high value and the other a low value. These effects were therefore evaluated using chi-square analysis after splitting the sample into high and low categories for each of the interacting variables (Table 3).

\section{RESULTS}

\section{Main Effects}

The main effect results confirm, with one exception, previous empirical findings in the entry mode literature. Larger and more multinational firms 


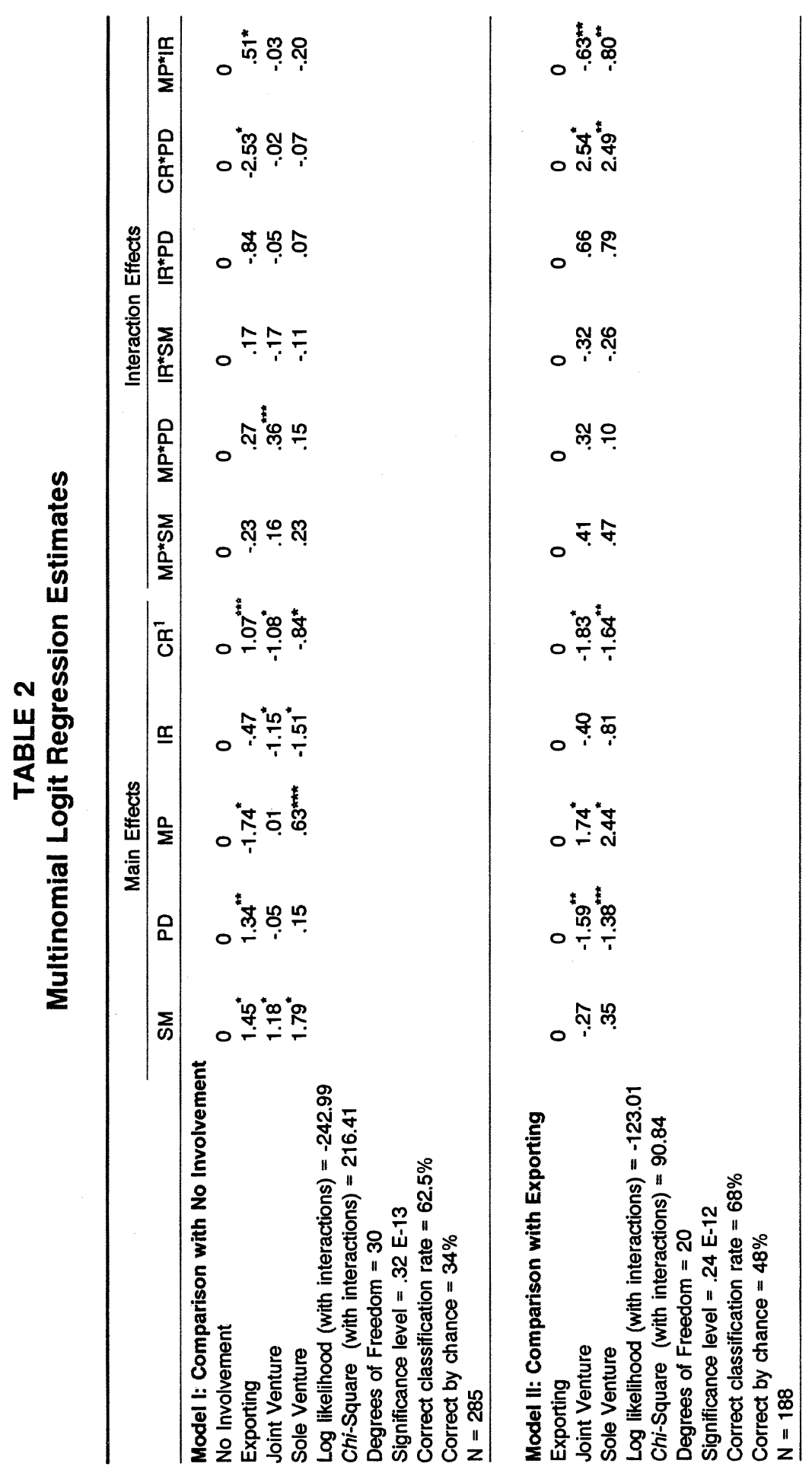




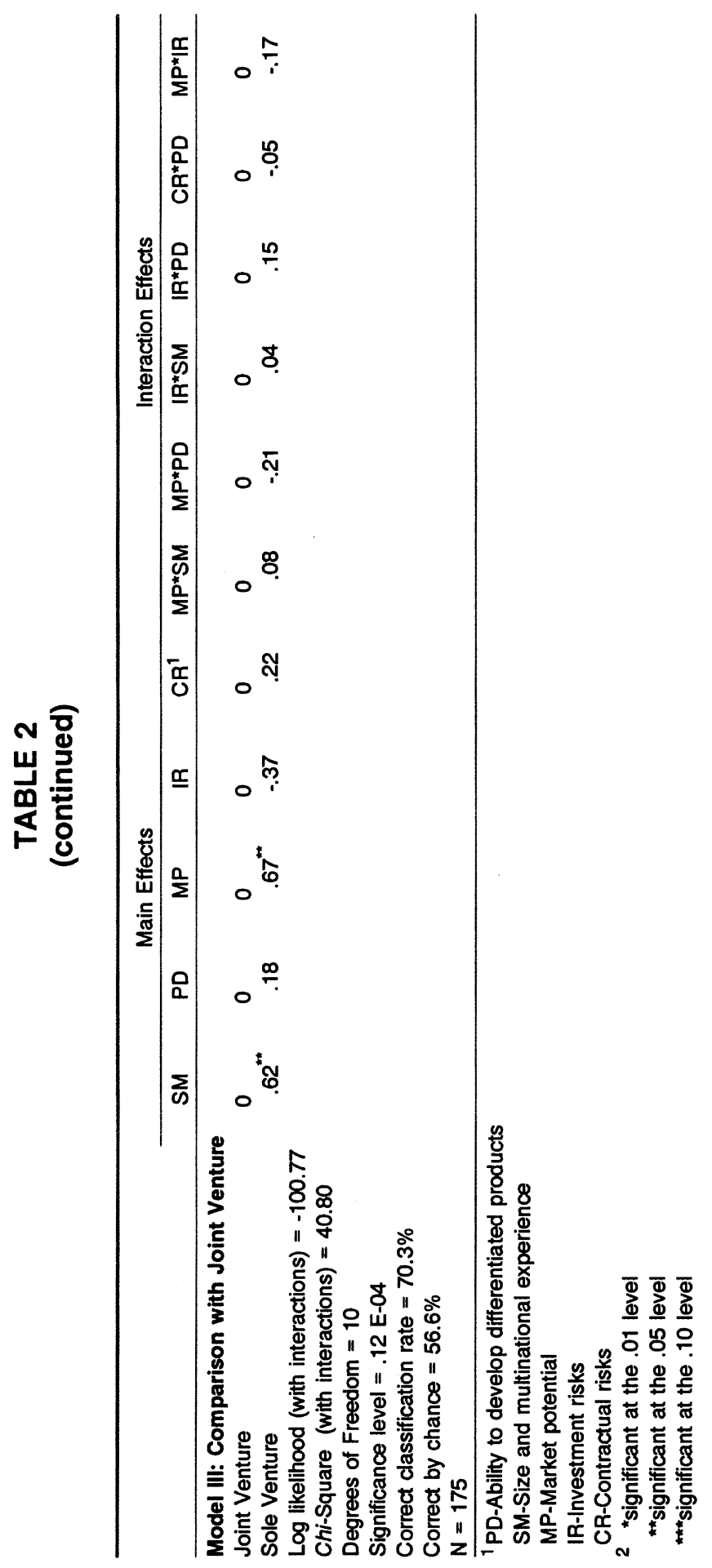


TABLE 3

\section{Association between Low/High Levels of Interaction Variables and Mode Choices}

1. Size/Multinational Experience (SM) and Market Potential (MP)

\begin{tabular}{lcccc} 
& NI & EXP & JV & SV \\
\hline Low SM and High MP & 31 & 1 & 25 & 12 \\
High SM and Low MP & 12 & 7 & 21 & 27 \\
Low SM and Low MP & 34 & 3 & 26 & 11 \\
High SM and High MP & 21 & 2 & 19 & 34 \\
\hline
\end{tabular}

Chi-Square $(9$ d.f. $)=37.47 p=0.000$

showed a greater tendency to enter foreign markets (Model I and II). Although they may choose any entry mode, if they chose to invest, they show a preference for a sole venture mode over a joint venture mode (Model III). While firms that have a high ability to develop differentiated products also had a greater tendency to enter foreign markets, they tended to prefer noninvestment modes (Model I and II). Except for the last result, the other main effect results support the role of ownership advantages as hypothesized in previous studies.

With reference to the location advantages, it was found that firms preferred to enter the more potential markets using investment modes (Model I and II) and among those markets that were chosen for investments, firms preferred sole venture in markets that were perceived to have higher market potential (Model III). On the other hand, firms tend to avoid markets that have high investment risks (Model I, II, and III), while choosing to only export to markets that have high contractual risks (Model I, II and III).

\section{Interaction Effects}

The interaction effects are evaluated using results from both logistic regression (Table 2) and cross-tabulation results (Table 3). The regression estimates provide information on the significance of the high/high and low/low combinations of the interacting variables, while the cross-tabulations examine the significance of the high/low and low/high combinations of the interacting variables. The results are presented for each hypothesis separately.

H1: Table 3 shows that larger and more multinational firms have a higher propensity to choose sole venture and joint venture modes, and a lower propensity for no involvement in low potential countries, supporting H1. This confirms our expectation that such firms may be guided more by strategic considerations than by cost-benefit trade-offs in such markets.

$\mathrm{H} 2$ : Table 3 also shows that smaller and less multinational firms have a higher propensity for no entry or entry through a joint 
venture mode in high potential markets, supporting H2. These firms are interested in expanding into high potential markets, but do not have the requisite resources to do so by themselves.

H3: Table 2 indicates that firms that have higher ability to develop differentiated products do not show preference for any specific entry mode in markets that have high investment risk, failing to support H3. The coefficients for sole venture and joint venture modes in Model II are positive (though non-significant) and may suggest that such firms may have a weak preference for investment modes, rather than exporting in these markets.

H4: As hypothesized, firms with higher ability to develop differentiated products show a preference for investment modes of entry in markets that are perceived to have higher contractual risks. Note that the main effect of contractual risks suggested a nonpreference for investment modes, implying that firms place a premium on retaining control over valuable assets and skills.

H5: Firms appear to prefer the exporting mode in markets that have high potential, but that are perceived to have high investment risks, partially supporting $\mathrm{H} 5$. This result implies that firms are interested in entering such markets, but would like to reduce their risk of investment loss.

\section{DISCUSSION OF RESULTS AND IMPLICATIONS}

The major objective of this study was to examine the effect of interrelationships among a firm's ownership (ability to develop differentiated products, size and multinational experience), location (market potential and investment risk) and internalization advantages (contractual risks) on its choice of entry modes in foreign markets. The results provide broad support for the hypothesized effects of the interrelationships, while simultaneously confirming previous findings on the separate effects of each type of determinant.

The findings of this study imply that though firms would like to establish market presence in foreign countries through direct investment, their ability to do so is constrained by their size and multinational experience. In addition, while the results support the general belief that firms use investment modes only in high potential markets, they also suggest that some firms (large multinationals) may invest in relatively lower potential markets if their strategic objectives dictate so. However, firms are hesitant to enter markets that are considered risky. Such caution appears understandable. The longterm success of any foreign investment requires significant managerial and financial resources even in markets that do not have high risks. In a high risk situation, firms could make a risk-averse choice resulting in the market being not served. 
In addition to the preference for investment modes by large multinational firms in lower potential markets, a number of other interesting interaction effects emerged from the study. First, small firms with limited multinational experience were found to prefer entry into markets that were perceived to have high potential through a joint venture. This result indicates that smaller, less multinationally experienced firms need to complement their resource needs in order to service a potentially attractive foreign market. As argued in the hypotheses section, the sharing of costs and risks enables such firms to reduce the long-term uncertainty more efficiently [Beamish and Banks 1987]. Second, firms that have higher ability to develop differentiated products are concerned about the possible loss of their advantage in countries that are perceived as having higher contractual risks. They show a strong dislike for the exporting mode, but are willing to choose investment modes in such markets. This can be attributed to the fact that the long-term success of leasing operations in a foreign market is highly dependent on a firm's ability to enforce contractual obligations by the lessee or the partner firm. In a personal interview with a leading multinational leasing firm, it was revealed that the firm did not wish to export equipment to a middle eastern nation because, regardless of the nature of the contract, the equipment became the property of the ruler of that nation. It is probably much safer to engage in leasing activity by investing in that nation and operating within the framework of the domestic laws. Third, the results reveal that while firms are interested in entering markets that are perceived to have high potential, the existence of investment risks leads them to shy away from investments. In such countries firms prefer to simply export. It is interesting to note that the main effect of investment risk suggested no entry while that of market potential suggested investment modes. The combined effect suggests that firms take a risk-averse stance and choose limited involvement in such markets.

From an entry mode perspective, exporting is preferred to (a) no involvement, if firms have the ability to develop differentiated products and if contractual risks are high (this effect is considerably weakened for firms with the ability to develop differentiated products); (b) a joint venture if contractual risks are high; and (c) a sole venture if contractual risks are high. On the other hand, preference for exporting is found to be relatively low in high potential markets indicating that high return/high risk investment modes are better modes in such markets. These results imply a tendency to avoid entry through exporting when the potential returns through other modes are high, and prefer entry through exporting when the potential risks for other modes are high.

The joint venture mode is preferred by larger and more multinational firms. It is also preferred by smaller and less multinational firms in high potential markets. On the other hand, this mode is not preferred when contractual and investment risks (even in high market potential countries) are high. When firms have the ability to develop differentiated products, they prefer this 
mode in higher potential markets and in markets that have higher contractual risks. The last result is perplexing, even though it stipulates that the main effect of contractual risks will be weakened by the presence of product differentiation ability.

The sole venture mode is also preferred by large, multinational firms (more so than those choosing joint venture), and in markets with higher potential. Firms, in general, do not prefer the sole venture when contractual and investment risks (even in high market potential countries) are high. But, when firms have higher ability to develop differentiated products, they may enter markets that are perceived to have high contractual risks using this mode. This means that firms tend to offset these risks through higher levels of product differentiation. This implies that firms draw greater market power not from size but from the advantages that they gain through product differentiation.

The trend towards globalization has meant that not only are multinational firms taking a global view of their strategies but also countries are beginning to recognize that their economic development strategies must take on a global dimension. This study shows that firms that have a higher preference for investment entry modes are sensitive to investment/contractual risk-related attributes. The governments in host countries, therefore, will not only have to develop policies that make it attractive for foreign firms to invest in their markets, but more importantly, will have to reduce their risk perceptions through regulations that permit repatriation of profits, majority ownership and control, patent protection for technology/products and enforcement of contracts. From the government's perspective, it should be noted that, regardless of the stage of economic development of the country, policy variables that reduce the risk will have a positive impact on inward foreign direct investment and technology transfer.

Recent trends indicate a move by developing countries to do just this, whereby conditions are being created for a more favorable investment climate through relaxation of investment controls and provision of investment incentives including better protection of property rights and enforcement of contracts. Under these circumstances, firms with higher ownership advantages can derive pioneering benefits by being the first to enter these countries. For instance, Pepsi gained entry into India through a complex contractual arrangement (with $39.9 \%$ equity joint venture) primarily because as the President and Chief Executive Officer of Pepsi-Cola International, Mr. Robert H. Beeby said, "We're willing to go so far with India because we wanted to make sure we get an early entry while the market is developing" [Spaeth and Naj 1988]. This gives Pepsi access to a large market that is expected to become less riskier in terms of enforcing contracts.

\section{LIMITATIONS AND CONCLUSIONS}

The major objective of this study was to examine the impact that interrelationships among ownership, location, and internalization advantage factors had 
on firms' choice of foreign market entry modes. The study provided support for most of the hypothesized relationships suggesting the importance of including interaction effects in the entry choice model. A future research agenda should be to test these interactions in other industries, as well as develop other relevant interactions. A novel feature of this study was the use of managerial perceptions for measuring the explanatory factors. The study showed that this method of operationalization was particularly useful for quantifying hitherto unquantifiable constructs. An important research direction is the development of better survey measures for those constructs that had relatively low inter-item consistency.

The results and implications drawn from this study should be viewed in light of the research method employed. Some of the inconsistencies we observed could have arisen from the nature of the sample. The sample came from a single industry and hence the generalizability of the results is limited. Caution must also be exercised in drawing cause-effect inferences from the study because of the use of cross-sectional data. The use of cross-sectional design limits our ability to rule out alternative causal inferences. Studies involving dynamic processes such as entry mode choice may require a temporal focus making longitudinal designs more appropriate. In spite of these limitations, this study is among the first to capture the effect of the three types of advantages and their interactions. Other studies could use our study as a basis for extending work in this area toward a better understanding of how managers make entry mode decisions.

\section{APPENDIX \\ Measurement Items}

\section{OWNERSHIP ADVANTAGES}

\section{Firm Size}

1. What is the gross volume of business conducted by your firm in the preceding financial year?

\section{Ability to Develop Differentiated Products}

2. How do you rate your training program in terms of preparing your personnel to conduct leasing transactions?

3. How do you rate your firm's potential to create new and creatively structured leasing transactions?

\section{Multinational Experience}

4. Approximately, what percentage of your total earnings would you attribute to your foreign source income?

5. How multinational do you think your firm is, in terms of number of countries operated in? 
6. How capable is your firm in terms of technological, managerial, and financial capabilities to handle international expansion?

\section{LOCATION ADVANTAGES}

\section{Market Potential}

7. What do you think is the market potential of leasing business in (country)?

8. What do you think is the growth potential of leasing business in (country)?

9. What do you think is the general acceptability of leasing as a financial tool in (country)?

10. What do you think about the attitude of government toward the leasing industry in (country)?

11. What do you think about the attitude of government toward foreign firms in general in (country)?

\section{Investment Risk}

12. What do you think about the general stability of the political, social, and economic conditions in (country)?

13. What do you think is the risk of converting and repatriating your income in (country)?

14. What do you think is the risk of expropriation of firms from (country).

\section{INTERNALIZATION ADVANTAGES}

\section{Contractual Risk}

15. Compared to that of the U.S.A., how would you rate the costs of making and enforcing contracts in (country)?

16. How sure are you that your standards of quality of services will be maintained if you operated jointly with a local leasing firm in (country)?

17. What do you think is the risk of dissipation or misuse of your proprietary knowledge if you operated jointly with a local leasing firm in (country)?

Note: All items (except 1 and 5) were measured using a 7-point bipolar scale.

\section{NOTES}

1. This study examines only one type of exporting, namely, direct exporting without investment of assets in the host country. Some studies in the international channels literature have found differences between direct exporting versus indirect exporting, and hence some of our hypotheses and their rationale may need to be modified for the indirect exporting context.

2. The only study that we know of that has examined interactions is by Gatignon and Anderson [1988]. They examined the effect of interaction between asset specificity and country risk on the choice 
between joint venture and sole venture. While these constructs are somewhat similar to ownership and location factors respectively, their study was based on the transaction cost framework proposed by Williamson. It should be noted, however, that they did not find a significant effect for this interaction term.

3. Empirical studies, because of their reliance on demographic or objective measures, have had difficulty in developing surrogate indicators of either costs and benefits or risks associated with internal versus external transactions. Cho [1985], for example, used 'assets and liabilities/total assets' of a firm and 'number of offshore markets' in which a firm has branch offices as indicators of internalization advantages. These measures clearly do not measure costs and benefits or risks. Further confusion arises because these measures have also been used as measures of ownership advantages of a firm in other studies (see, e.g., Caves and Mehra [1986]; Kogut and Singh [1988]). Similar operationalization problems were encountered by Dunning [1980]. In this study, we overcome these difficulties by directly measuring managerial perceptions of different types of contractual risks that can be expected in transactions in a particular host country.

4. Most previous studies have measured the location advantages of a host country using demographic indicators such as GDP, population, literacy rate, urban population, etc. to measure the market potential and country restrictiveness as a measure of investment risk. The values of such variables are constant across all firms and industries for a particular host country.

5. Our focus in this study is on market-seeking firms and not resource-seeking firms. Hence, we do not include the level of resource abundance in a particular host country as a location factor.

6. Contrary to our expectation, only two firms chose licensing in our sample. We have therefore deleted this option from the analysis.

\section{REFERENCES}

Anderson, Erin \& Anne T. Coughlan. 1987. International market entry and expansion via independent or integrated channels of distribution. Journal of Marketing, 51 (January): 71-82.

Anderson, Erin \& Hubert Gatignon. 1986. Modes of foreign entry: A transaction cost analysis and propositions. Journal of International Business Studies, 17 (Fall): 1-26.

Anderson, Erin \& Barton Weitz. 1986. Make or buy decisions: A framework for analyzing vertical integration issues in marketing. Sloan Management Review, 27 (Spring): 3-19.

Bartlett, Christopher A. 1986. Building and managing the transnational: The new organizational challenge. In Michael E. Porter, editor, Competition in global industries. Boston: Harvard Business Press.

\& Sumantra Ghoshal. 1986. Tap your subsidiaries for global reach. Harvard Business Review, November-December: 87-94.

Boddewyn, Jean J., Marsha B. Halbrich \& Anne C. Perry. 1986. Service multinational: Conceptualization, measurement and theory. Journal of International Business Studies, 17 (Fall): 41-58.

Beamish, Paul W. \& John C. Banks. 1987. Equity joint ventures and the theory of the multinational enterprise. Journal of International Business Studies, 18 (Summer): 1-16.

Buckley, Peter J. 1988. The limits of explanation: Testing the internalization theory of the multinational enterprise. Journal of International Business Studies, 19 (Summer): 181-94.

\& Mark C. Casson. 1976. The future of multinational enterprise. New York: Holmes \& Meier Publishers.

Caves, Richard E. 1982. Multinational enterprise and economic analysis. New York: Cambridge University Press.

\& Sanjeev K. Mehra. 1986. Entry of foreign multinationals into U.S. manufacturing industries. In Michael E. Porter, editor, Competition in global industries. Boston: Harvard Business Press.

Cespedes, Frank V. 1988. Control vs. resources in channel design: Distribution differences in one industry. Industrial Marketing Management, 17: 215-27.

Cho, Kang Rae. 1985. Multinational banks: Their identities and determinants. Ann Arbor: UMI Research Press.

Choi, Sang-Rim, Adrian E. Tschoegl \& Chwo-Ming Yu. 1986. Banks and the world's major financial centers, 1970-1980. Welwirtschaftliches Archive, 1: 48-64. 
Clark, Tom M. 1985. An international movement in leasing. In World Leasing Yearbook. London: Hawkins Publishers Ltd.

Cooper, Lee G. \& Masao Nakanishi. 1983. Standardizing variables in multiplicative choice models. Journal of Consumer Research, 10 (June): 96-108.

Contractor, Farok J. \& Peter Lorange. 1988. Competition vs. cooperation: A benefit/cost framework for choosing between fully-owned investments and cooperative relationships. Management International Review, Special Issue: 5-18.

Coughlan, Anne T. 1985. Competition and cooperation in marketing channel choice: Theory and application. Marketing Science, 4(2): 110-29.

\& M. Therese Flaherty. 1983. Measuring the international marketing productivity of U.S. semiconductor companies. In David Gautschi, editor, Productivity and distribution. Amsterdam: Elsevier Science Publishing Co.

Cyert, Richard M. \& James G. March. 1963. A behavioral theory of the firm. Englewood Cliffs, NJ: Prentice-Hall.

Davidson, William H. 1982. Global strategic management. New York: John Wiley.

\& Donald G. McFetridge. 1985. Key characteristics in the choice of international transfer mode. Journal of International Business Studies, 16 (Summer): 5-22.

Doz, Yves L. 1988. Technology partnerships between larger and smaller firms: Some critical issues. International Studies of Management and Organization, 17(4): 31-57.

, C.K. Prahalad \& Gary Hamel. 1988. Competitive collaboration. In Farok J. Contractor \& Peter Lorange, editors, Cooperative strategies in international business. Lexington, Mass.: Lexington Books.

Dubin, Michael. 1975. Foreign acquisitions and the spread of the multinational firm. D.B.A. thesis, Graduate School of Business Administration, Harvard Business School.

Dunning, John H. 1977. Trade, location of economic activity and the MNE: A search for an eclectic approach. In Bertil Ohlin et al., editors, The international allocation of economic activity. Proceedings of a Noble Symposium held in Stockholm, London: Macmillan.

1980. Toward an eclectic theory of international production: Some empirical tests. Journal of International Business Studies, 11 (Spring/Summer): 9-31.

1988. The eclectic paradigm of international production: A restatement and some possible extensions. Journal of International Business Studies, 19 (Spring): 1-31.

Eaton, Jonathan \& Mark Gersovitz. 1983. Country risk: Economic aspects. In Richard J. Herring, editor, Managing international risk. Cambridge: Cambridge University Press.

Fagre, Nathan \& Louis T. Wells, Jr. 1982. Bargaining power of multinationals and host governments. Journal of International Business, 13 (Fall): 9-24.

Fayerweather, John. 1982. International business strategy and administration. Cambridge: Ballinger.

Forsyth, David J.C. 1972. U.S. investment in Scotland. New York: Praeger Press.

Gatignon, Hubert A. \& Erin Anderson. 1988. The multinational corporation's degree of control over foreign subsidiaries: An empirical test of a transaction cost explanation. Journal of Law, Economics and Organization, 4(2): 305-36.

Gray, Jean \& Peter H. Gray. 1981. The multinational bank: A financial MNC. Journal of Banking and Finance, 5: 33-63.

Harrigan, Kathryn R. 1985. Strategies for joint ventures. Lexington, Mass.: D.C. Heath \& Co.

Herring, Richard J. 1983. Managing international risk. Cambridge: Cambridge University Press.

Hill, Charles W.L., Peter Hwang \& W. Chan Kim. 1990. An eclectic theory of the choice of international entry mode. Strategic Management Journal, 11: 117-28.

Hood, Neil \& Stephen Young. 1979. The economics of multinational enterprise. London: Longman Group Ltd.

Huber, George P. \& Daniel J. Power. 1985. Retrospective reports of strategic-level managers: Guidelines for increasing their accuracy. Strategic Management Journal, 6: 171-80.

Khoury, Sarkis, J. 1979. International banking: A special look at foreign banks in the U.S. Journal of International Business Studies, 10 (Winter): 36-52. 
Kimura, Yui. 1989. Firm specific strategic advantages and foreign direct investment behavior of firms: The case of Japanese semi-conductor firms. Journal of International Business Studies, 20 (Summer): 296-314.

Kogut, Bruce. 1989. A note on global strategies. Strategic Management Journal, 10: 383-89.

\& Harbir Singh. 1988. The effect of national culture on the choice of entry mode. Journal of International Business Studies, 19 (Fall): 411-32.

Kumar, Manmohan S. 1984. Growth, acquisition, and investment: An analysis of the growth of industrial firms and their overseas activities. Cambridge: Cambridge University Press.

Lambkin, Mary. 1988. Order of entry and performance in new markets. Strategic Management Journal, 9: $127-40$.

Lecraw, Donald J. 1984. Bargaining power, ownership, and profitability of subsidiaries of transnational corporations in developing countries. Journal of International Business, 15 (Spring/Summer): 2744.

Leontiades, James C. 1985. Multinational corporate strategy: Planning for worldwide markets. Lexington, Mass.: Lexington Books.

Meidan, A. 1984. Strategic problems in international leasing. Management International Review, 24(4): 36-45.

Norburn, David \& Sue Birley. 1988. The top management team and corporate performance. Strategic Management Journal, 9: 225-37.

Nunnally, Jum C. 1978. Psychometric theory. New York: McGraw Hill.

Parrish, Karl M. 1983. International leasing. In William H. Baughn \& Donald R. Mandich, editors, The international banking handbook. Homewood, Ill.: Dow Jones-Irwin.

Porter, Michael E. \& Mark B. Fuller. 1986. Coalitions and global strategy. In Michael E. Porter, editor, Competition in global industries. Boston: Harvard Business Press.

Prahalad, C.K. \& Yves L. Doz. 1987. The multinational mission: Balancing local demands and global vision. New York: Free Press.

Root, Franklin R. 1987. Entry strategies for international markets. Lexington, Mass.: D.C. Heath.

Rugman, Alan M. 1979. International diversification and the multinational enterprise. Lexington, Mass.: D.C. Heath.

1981. Inside the multinationals: The economics of internal markets. New York: Columbia University Press.

1982. Internalization and non-equity forms of international involvement. In Alan M. Rugman, editor, New theories of the multinational enterprise. London: Croom Helm.

Sabi, Manijeh. 1988. An application of the theory of foreign direct investment to multinational banking in LDCs. Journal of International Business Studies, 19 (Fall): 433-48.

Spaeth, Anthony \& Amal K. Naj. 1988. PepsiCo accepts tough conditions for the right to sell cola in India. Wall Street Journal, September 20: 42.

Stopford, John. M. \& Louis T. Wells. 1972. Managing the multinational enterprise: Organization of the firm and ownership of the subsidiaries. New York: Basic Books.

Talaga, James, Rajan Chandran \& Arvind Phatak. 1985. An extension of the eclectic theory of foreign direct investment. A paper presented at the Annual Meeting of the Academy of International Business, New York.

Terpstra, Vern \& Chwo-Ming Yu. 1988. Determinants of foreign investment of U.S. advertising agencies. Journal of International Business Studies, 19 (Spring): 33-46.

Ting, Wen Lee. 1988. Multinational risk assessment and management. New York: Quorum Books.

Van de Ven, Andrew H. \& Marshall S. Poole. 1989. Paradoxical requirements for a theory of organizational change. In Andrew H. Van de Ven, Harold L. Angle \& Marshall S. Poole, editors, Research on the management of innovation: The Minnesota studies. Cambridge: Ballinger.

Vernon, Raymond. 1983. Organizational and institutional responses to international risk. In Richard J. Herring, editor, Managing international risk. Cambridge: Cambridge University Press.

Weinstein, Arnold, K. 1977. Foreign investments by service firms: The case of the multinational advertising agency. Journal of International Business Studies, 8 (Spring-Summer): 83-91. 
Williamson, Oliver E. 1985. The economic institutions of capitalism. New York: The Free Press.

Wilson, Brent D. 1980. Disinvestment of foreign subsidiaries. Ann Arbor: UMI Press.

Yannopoulos, George. 1983. The growth of transnational banking. In Mark Casson, editor, The growth of international business. London: George Allen \& Unwin.

Yu, Chwo-Ming \& Kiyohiko Ito. 1988. Oligopolistic reaction and foreign direct investment: The case of the U.S. tire and textile industries. Journal of International Business Studies, 19 (Fall): 449-60. 